\title{
Kveile ein coil
}

Kan vi kveile eit aneurisme i staden for å coile det?

Eit aneurisme kan vere skrekkelege saker, særleg når det sprekk. Det rumperte cerebrale aneurismet er hovudårsaka til spontan subaraknoidalbløding som står for $3 \%$ av alle hjerneslaga, med ein dødelegheit på kring $50 \%$ (1). Om ein tilfeldig oppdagar eit aneurisme, kan ein behandle det ved å coile det. Ved hjelp av eit mikrokateter går ein inn endovaskulært til aneurismet og pakkar det fullt med ein metalltråd som gjer at blodet koagulerer kring tråden, slik at aneurismet på elegant vis blir tett (1).

Det engelske ordet coil stammar opphavleg frå det latinske colligere («å samle») og er oftast nytta som sjøuttrykk i meininga «ein ring av tauverk» (2). I Noreg har vi i lange tider omsett taurullen til kveil slik at det skal klinge litt betre for norske øyre, og Norsk ordbok definerer kveil som «ringer av opprullet tau el. slange» (2). Ifølgje Kunnskapsforlagets store engelskordbok har coil ytterlegare to norske tydingar, nemleg som ein elektronisk spole og som prevensjonsmiddelet spiral (3). Medan ein på engelsk har gjeve ordet coil ei ny tyding innan endovaskulær aneurismekirurgi, har vi ikkje gripe sjansen til å finne eit norsk avløysarord - vi har etter gammal vane ukritisk slege armane kring det engelske.

Avløysarordet kveil lyder godt, har like mange stavingar og kling like godt som verb og -ing-form: å kveile-kveiling (jf. coile og coiling). Når ein nyttar eit norsk ord, er det brått meir intuitivt for pasientane kva ein gjer under intervensjonen òg, nemleg at ein skal kveile ein tråd inn i aneurismet.

Sjølv om trådinnpakkinga $\mathrm{i}$ aneurismet av radiologen kanskje ikkje ser like fint oppkveila ut som kveilen til dagens duglege matrosar, er det likevel eit flott avløysarord som er verdt ein plass i det norske, medisinske vokabularet.

Kasper Schei

kaspersc@stud.ntnu.no
Kasper Schei (f. 1992) er medisinstudent ved Norges teknisk-naturvitenskapelige universitet.

Litteratur

1. Bakke SJ, Lindegaard K-F. Subaraknoidalblødning - diagnostikk og behandling. Tidsskr Nor Lægeforen 2007; 127: 1074-8

2. Ordnett.no. Kveil. Norsk ordbok. http://ordnett.no/ search?search=kveil\&lang=no (30.5.2014).

3. Ordnett.no. Coil. Kunnskapsforlagets store engelskordbok. http://ordnett.no/search?search=coil\&lang= en (20.6.2014)

Mottatt 20.6.2014, første revisjon innsendt 1.8. 2014, godkjent 1.8.2014. Redaktør: Marit Skaar Fjellhaug.

\section{Dialogkonferanse - en pleonasme}

\section{Både dialog og konferanse betyr samtale, og derfor blir dialogkonferanse et selvrepeterende uttrykk.}

Dialogkonferansen 2014 om ledelse og sykehus er omtalt i Tidsskriftet som en viktig møteplass (1). Selv har jeg grunnet på hva neologismene «dialogkonferanse» og «dialogmøte» betyr og har derfor søkt leksikal hjelp. Ifølge Ordbok for underklassen er dialogmøter en utbredt aktivitet i forvaltning og helseinstitusjoner. Ordet dialogmøte er en manipulasjon av språket for å opphøye ledere til personer med mytiske egenskaper (2).

I norsk dagligtale betyr dialog samtale mellom to eller flere personer (3). I møter og konferanser er det som regel to eller flere personer som taler sammen. Dialogmøter og dialogkonferanser er følgelig pleonasmer, noe vi lærte på skolen at vi skulle unngå.

Ordbokens forfattere skriver at dialog kommer fra gresk og latin og er sammensatt av ordene dia, som betyr to, og logos, som betyr ord, tale eller fornuft. Forfatterne er på villspor. Dia er en gresk preposisjon som betyr gjennom, mellom, ved eller liknende, slik medisinere kjenner den i diabetes og diagnose. Når ordbokforfatterne skriver at dia betyr to, kan de ha tenkt på prefikset $d i$, som i kjemisk sammenheng betyr to eller to ganger, som i dimetyl og dioksyd.

Tallet to heter duo på både gresk og latin. Ordet dialog som forstavelse gir liten mening til rotordene konferanse og møte. Kanskje neste års dialogkonferanse blir avmytisert til Leder-og sykehuskonferansen 2015 ?
Aksel Ongre (f. 1934) er pensjonert radiolog.

Litteratur

1. Wærnes D. Å lede er å lytte. Tidsskr Nor Legeforen 2014: 134: 1005.

2. Klyve A, Severud J. Ordbok for underklassen. Oslo: Spartacus, 2013: 8, 42.

3. Bokmålsordboka. www.nob-ordbok.uio.no/perl/ ordbok.cgi?OPP =dialog \&begge $=+\&$ ordbok $=$ bokmaal (27.5.2014).

Mottatt 16.5. 2014, første revisjon innsendt 25.5. 2014, godkjent 27.5. 2014. Redaktør: Marit Skaar Fjellhaug. 